\title{
The Effect of Foreign Direct Investment, Human Development and Macroeconomic Condition on Economic Growth: Evidence from Indonesia
}

\author{
${ }^{1}$ Ridha, M. Risamawan \& ${ }^{2}$ Budi, Novia \\ ${ }^{*}$ Badan Pusat Statistik, Kabupaten Maluku Tengah, Maluku, \\ 2 STIS Jakarta, Politeknik Statistika, Jakarta
}

\begin{tabular}{|c|c|}
\hline ARTICLE DETAILS & \multirow{6}{*}{$\begin{array}{l}\text { ABSTRACT } \\
\text { The national economic growth that is quite high is not necessarily } \\
\text { detached from the existence of important issues such as limited } \\
\text { accumulation of national saving capital, domestic needs that are } \\
\text { still highly dependent on imported goods, weak of export that rely } \\
\text { on primary commodities, insufficient infrastructure development, } \\
\text { and low quality of human resources that must be addressed by } \\
\text { the Indonesian government. This study aims to analyze the effect } \\
\text { of Foreign Direct Investment (FDI), as an alternative source of } \\
\text { development funds, the Human Development Index (HDI) as a } \\
\text { proxy for the quality of human resources, and Macroeconomic } \\
\text { condition represent by Trade Balance (NX), a dummy of } \\
\text { Economic Crisis and Gross Fixed Capital Formation (GFCF) on } \\
\text { Economic Growth in Indonesia. The data used is time-series data } \\
\text { from the period of } 1985-2015 \text { sourced from Statistics Indonesia } \\
\text { and the World Bank. The analysis technique used in this research } \\
\text { is the Error Correction Model (ECM). The results obtained can be } \\
\text { made in the following conclusions: } 1 \text { ) Foreign Direct Investment } \\
\text { and Trade Balance have a negative and significant impact on } \\
\text { Indonesia's long term economic growth, but in the short term, } \\
\text { they do not have any significant impact. 2) Human Development } \\
\text { and Gross Fixed Capital Formation have a positive and } \\
\text { significant impact on Indonesia's economic growth both in the } \\
\text { long term and short term. 3) Economic Crisis has a negative and } \\
\text { significant impact both in the long term and short term. }\end{array}$} \\
\hline $\begin{array}{l}\text { Article History } \\
\text { Published Online: }\end{array}$ & \\
\hline $\begin{array}{l}\text { JIAE (Journal Indonesian Applied } \\
\text { Economic) }\end{array}$ & \\
\hline $\begin{array}{l}\text { Keywords } \\
\text { Economic Growth, Foreign Direct } \\
\text { Investment, Human Development, } \\
\text { Macroeconomic Condition, ECM }\end{array}$ & \\
\hline${ }^{*}$ Corresponding Author & \\
\hline $\begin{array}{l}\text { Email: Email address of } \\
\text { rismawan.ridha@bps.go.id }\end{array}$ & \\
\hline
\end{tabular}

JEL Classification: F43, P45

\section{INTRODUCTION}

Development is a multidimensional process involving major changes in social structures, popular attitudes, and national institutions, as well as the acceleration of economic growth, the reduction of inequality, and the eradication of poverty (Todaro, 2017). One indicator that used to measure the success of the development is economic growth. Economic growth is an increase in the production of goods and services in a country, compared from one period of time to another.

Nowadays, every country is competing to create high economic growth. According to Bank Indonesia in 2013, the ASEAN region is an area that has a very dynamic economic growth in which Indonesia is one of the countries in the region that is experiencing the fastest economic growth. The World Economic Forum (2016) even predicts Indonesia as one of the leading economies in the future.

If explored further, economic growth in Indonesia tends to fluctuate. In the 1985-1995 period, the average annual rate of economic growth in Indonesia was 6.31 percent, which classified as high economic growth. However, the brilliance of this economic development cannot last longer than expected. The Indonesian economy experienced a setback in the 1997-1998 period due to the monetary crisis that hit Asian. This deep economic recession 


\section{The Effect of Foreign Direct Investment, Human Development and Macroeconomic Condition on Economic Growth: Evidence from Indonesia}

recorded a historical rate of Indonesia's economic growth, which reached negative 14.35 percent. This negative growth rate is far greater than the highest positive growth that occurred during the Orde Baru era, which averaged 7 to 8 percent per year. After experiencing a setback, starting in 2000 , the Indonesian economy seemed to improve. Indonesia's economy can recover to 4.92 percent in 2000, and between 2001-2015 Indonesia's averaged 5.33 percent per year.

To become a leading economic country, Indonesia still has many economic problems that must be addressed immediately. The Macroeconomic Condition, which represents by the domestic needs that are still highly dependent on imported goods, weak exports that only rely on primary commodities, and insufficient infrastructure development have left Indonesia very vulnerable to crises and other external shocks (Tambunan, 2011). Another serious problem that often occurs is the budget deficit. This condition causes Indonesia's inability to fund its development activities. Besides, the low quality of human resources in Indonesia also contributes to Indonesia's economic problems.

Development policies implemented by the Indonesian government produce development expenditure that is quite high and tends to continue to increase every year while the revenue budget constrains that can be collected is inadequate. As a result, the difference between funds from routine budgets by the government is unable to guarantee the continuity of Indonesia's development. To cover the lack of development funding sources, Indonesia has always been dependent on international loans or foreign debt. However, in recent years, there has been a decline in development aid programs and increasingly difficult to obtain access to international loans through financial institutions (Rivayani, 2003 and Tambunan, 2011). As for developing countries like Indonesia, which always faced with the problem of limited national capital accumulation, Foreign Direct Investment (FDI) is an alternative source of funding and technology transfer.

According to economists, in addition to technological advancements represented by FDI, one of the most important factors in explaining economic growth is the quality of human development (Blomstrom and Kokko, 2003). Based on data from Statistics Indonesia (2015), the largest proportion of the total working population in Indonesia is dominated by those with low education. The implication is the domestic labor market dominated by workers with low levels of productivity and skills. This condition indicates that the quality of human resources is still low, which certainly has an impact on economic growth in Indonesia.

There are several studies conducted to find out the effect of FDI, the quality of human development and macroeconomic variables on economic growth. Kotler (1997) pointed out that the economy of a nation influenced by the abundance of economic resources, which include natural resources, population, human capital, technology, and infrastructure. Borenztein et al. (2001) conducted a study that examined the relationship between FDI and Human Capital with its relation to other macroeconomic variables to economic growth in 69 developing countries. Important results from this study indicate that the impact of FDI on economic growth depends on the quality of human capital owned by the host country. Partially, human capital has a positive effect on economic growth. But in practice, FDI will only have a positive effect on economic growth only when the host country can absorb enough technology. FDI productivity will occur if the host country has a minimum limit of human capital stock. FDI will not contribute to economic growth or negatively impact the economic growth of a country that has low-quality human capital.

Cao and Jariyapan (2012) estimated the effect of FDI, Human Capital on economic growth using panel data analysis in the People's Republic of China. They found that FDI has no significant effect and unable to create a major contribution to increase economic growth. Similar results also obtained from the study conducted by Carkovic and Levine (2002). However, there is a strong complementary effect between FDI and Human Capital in achieving economic growth. FDI can create enormous positive effects when interacting with the appropriate level of Human Capital.

A study by Alfaro (2003) using panel data analysis methods in 47 countries, found that FDI, in general, has a positive but statistically insignificant effect. Uniquely, FDI in the services and manufacturing sectors has a positive effect, but the primary sector has a negative effect because it tends to damage the environment. This research shows that not all FDI can provide benefits to economic growth. In the meantime, a study conducted by Ranis et al. (2000) tries to see partially the influence of Human Development on economic growth. This study provides results that Human Development has a positive and significant influence on economic growth. High Human Development indicates that a country's population has better health, higher education, and an adequate level of welfare, so they will contribute better through 
increasing their productivity and creativity in producing output effectively and efficiently.

As a study conducted by Adhikary (2011) analyzing the relationship between FDI, Trade Openness, Capital Formation, and Economic Growth in Bangladesh from the period of 1986 -2008, he found that FDI and Capital Formation have a positive influence on economic growth. Meanwhile, Trade Openness has a negative effect on economic growth. This result is in line with Aisyah (2011). Besides FDI and Capital Formation, the study also found that the Economic Crisis and Trade Balance has a negative effect on economic growth.

As an attempt to improve upon previous studies, firstly, the study tests the empirical relationship integrally between Foreign Direct Investment and Human Development in Indonesia. Secondly, most of the previous research used panel data analysis. This study employs the Error Correction Model that utilizing the error term to analyze the particular effect, both in the long term and short term.

The rest of this study is organized as follows. The second section describes the theoretical review used in this study. The third section discusses the data and econometric methodology used in the analysis. The fourth section analyses the main findings. Finally, the last section provides a conclusion.

\section{THEORETICAL REVIEW}

\section{Economic Growth}

Economic growth may be defined as a long-term rise in capacity to supply increasingly diverse economic goods to its population this growing capacity based on advancing technology and the institutional and ideological adjustments that it demands (Kuznets, 1973). Economic growth shows the extent to which economic activity will generate additional income for the community. To measure economic growth, economists use data on Gross Domestic Product (GDP), which measures the total income of everyone in the economy.

\section{Foreign Direct Investment}

Foreign Direct Investment (FDI) is an overseas equity investment by private Multinational Corporations (MNC). As a form of international capital flow for developing countries, FDI presents a unique opportunity such as company establishment, construction of factories, purchase of capital goods, land, and raw materials and supplies where investors are directly involved in its operations (Hady, 2001).

\section{Human Development}

Human Development is a process of enlarging people's choices. The most critical ones are to lead a long and healthy life, to be educated, and to enjoy a decent standard of living (UNDP, 1990). The term of human development here also denotes the level of their achieved well-being. It helps to distinguish clearly between two sides of human development. One is the formation of human capabilities, such as improved health or knowledge. The other is the use that people make of their acquired capabilities, for work and leisure.

\section{Other Macroeconomics Variables}

\section{Trade Balance (Net Export)}

Trade Balance is a reflection of a country's position in international capital markets, whether they are a net borrower or a net lender. It indicates the trade in goods and services differs from the benchmark of equal imports and exports. Salvatore (1996) pointed out that international trade used as an engine of growth for a country's economy.

\section{Gross Fixed Capital Formation}

Gross Fixed Capital Formation (GFCF) contains resident producer's acquisitions, less disposals, of fixed assets during a given period plus certain additions to the worth of nonproduced assets realized by the productive activity of the producer or institutional units. Fixed assets are produced assets used in production for more than 1 year, such as buildings, machinery, transport equipment, or intellectual property such as software or the results of research and development (Eurostat, 2013).

\section{Economic Crisis}

The economic crisis in economic sciences is a period of significant negative economic development of a country that presents a process of capital depreciation. The economic crisis, according to Tambunan (2011), classified as two. First, the economic crisis that occurred suddenly or appeared without any prior sign. An example of this crisis is the Asian financial crisis that occurred from 1997-1998. Second, the economic crisis that goes through a process of accumulation that is quite long, which is like the global financial crisis that occurred from 2008-2009. 


\section{The Effect of Foreign Direct Investment, Human Development and Macroeconomic Condition on Economic Growth: Evidence from Indonesia}

\section{DATA AND RESEARCH METHODOLOGY}

\section{Data}

The empirical analysis conducted using annual observations of Gross Domestic Product (GDP), Foreign Direct Investment (FDI), Human Development Index (HDI), Trade Balance (NX), Gross Fixed Capital Formation (GFCF), and dummy variable of the economic crisis from the period of 1985-2015. All data were obtained from the World Bank and Statistics Indonesia. Economic growth approached by using Natural Logarithm of GDP, while HDI is a composite index consisted of mean years schooling, expected years of schooling, and Gross National Income (GNI) per capita. A dummy variable of the economic crisis, which is for some observation year, has a value of 1 that presents a crisis occurring in that year (19971998 economic crisis and the 2008-2009 global financial crisis). Otherwise, the value of 0 represents the absence of the economic crisis in other years.

\section{Research Methodology}

This paper employs an Error Correction Model (ECM) that attempts to see the effect of long term and short term each of the independent variables to the variable bound. This method is a widely popular analysis to test whether the empirical model is consistent with economic theory. The methods allow the analysis of time series data that is not stationary at the level but stationary at the same level of integration.

The empirical process comprises four parts. First, the unit root test is applied to test the degree of integration of the variables. We performed the unit root test by using the Augmented Dickey-Fuller (ADF) test. Once the order of integration formed, we then establish the long term equation by applying regression with the OLS estimation method. The long term equation is as follow:

$$
\begin{gathered}
\operatorname{LNGDP}_{t}=\alpha_{0}+\alpha_{1} \text { FDI }_{t}+\alpha_{2} \mathrm{HDI}_{t}+\alpha_{3} N X_{t}+\alpha_{4} \text { GFCF }_{t} \\
+\alpha_{5} \text { Crisis }_{t}+\varepsilon_{t} \alpha_{i}
\end{gathered}
$$

Description:

$L N G D P_{t}$ : t-period Natural logarithm of GDP

$\boldsymbol{F D I}_{t}$ :t-period Foreign Direct Investment

$H_{D I}$ :t-period Human Development Index

$N X_{t}$ : t-period Trade Balance (Net Exports)

$G F C F_{t}$ : t-period Gross Fixed Capital Formation

Crisis $_{t}$ : t-period dummy of Economic

Crisis

$\varepsilon_{t}: \mathrm{t}$-period Error term

: Coefficient of long term equation
After establishing the long term equation, it is necessary to check whether there is cointegration or not. Cointegration essentially means the time series have a long-run relationship. If there isn't a long-run relationship, an ECM method is not appropriate. We perform a test on the residuals for stationarity using Johansen Cointegration Test. Now that we have our residuals and have differenced our data, we can attach the residuals to our data set and lag them by one period to estimate the Error Correction Model. The short term equation is as follows:

$$
\begin{aligned}
D\left(\text { LNGDP }_{t}\right)=\beta_{0}+ & \beta_{1} D\left(F D I_{t}\right)+\beta_{2} D\left(H D I_{t}\right)+\beta_{3} D\left(N X_{t}\right) \\
& +\beta_{4} D\left(G F C F_{t}\right)+\beta_{5} \text { Crisis }_{t}+\beta_{6} \varepsilon_{t-1}+\mu_{t}
\end{aligned}
$$

Description:

$\varepsilon_{t-1} \quad$ :Lag from Error Correction Term

$\boldsymbol{\beta}_{i} \quad$ :Coefficient of short term equation

$\mu_{t} \quad$ :White noise error term

\section{EMPIRICAL RESULT}

The analyzed time series were examined by unit-roots test to establish the order of integration. It is necessary since the estimation of non-stationary data will lead to the emergence of super inconsistencies and spurious regression (Gujarati, 2004). A unit root test of the Augmented Dickey-Fuller (ADF) unit carried out to determine whether the data is stationary or not. As presented in Table 1, the value of the ADF t-statistic of all variables is less than the particular MacKinnon critical value, which leads to the conclusion that all variables are not stationary at level. Therefore, it needs to continue with the first integration degree test. 
Table 1. Unit Root Test at the Level Phase Source: Author's Calculation

\begin{tabular}{|c|c|c|c|c|c|}
\hline \multirow[t]{2}{*}{ Variable } & \multirow{2}{*}{$\begin{array}{c}\text { ADF } \\
\text { t- } \\
\text { stats }\end{array}$} & \multicolumn{3}{|c|}{$\begin{array}{c}\text { MacKinnon Critical } \\
\text { Value }\end{array}$} & \multirow[t]{2}{*}{ Description } \\
\hline & & $1 \%$ & $5 \%$ & $10 \%$ & \\
\hline & $\overline{0} .325$ & & & & Non \\
\hline LNGDP & 6 & -3.6701 & -2.9639 & -2.6210 & Stationary \\
\hline & 0.471 & & & & Non \\
\hline FDI & 1 & -3.6701 & -2.9639 & -2.6210 & Stationary \\
\hline & 0.202 & & & & Non \\
\hline HDI & $\begin{array}{l}0 \\
2.319\end{array}$ & -3.6701 & -2.9639 & -2.6210 & $\begin{array}{l}\text { Stationary } \\
\text { Non }\end{array}$ \\
\hline NX & $\begin{array}{l}2 \\
1.157\end{array}$ & -3.6701 & -2.9639 & -2.6210 & $\begin{array}{l}\text { Stationary } \\
\text { Non }\end{array}$ \\
\hline GFCF & 2 & -3.6701 & -2.9639 & -2.6210 & Stationary \\
\hline
\end{tabular}

The null hypothesis state that variables assume common and individual unit root processes cannot be rejected. As presented in Table 2, after applying at the first difference, the ADF t-statistic of all variables in this study is greater than MacKinnon Critical Value at 5 percent and 10 percent level of significance. This result means that all variables meet the integrated requirement (stationary).

Table 2. Unit Root Test at the First Difference

\begin{tabular}{lrrrrr}
\hline \multirow{2}{*}{ Variable } & \multirow{2}{*}{$\begin{array}{c}\text { ADF } \\
\text { t-stats }\end{array}$} & \multicolumn{3}{c}{ MacKinnon Critical } & \\
\cline { 3 - 5 } & & $1 \%$ & $5 \%$ & $10 \%$ & \\
\hline D & & & & - & \\
(LNGDP) & -3.9265 & -3.6793 & -2.9677 & 2.6229 & Stationary \\
& & & & - & \\
D (FDI) & -5.0538 & -3.6793 & -2.9677 & 2.6229 & Stationary \\
& & & & - & \\
D (HDI) & -3.6560 & -3.6793 & -2.9677 & 2.6229 & Stationary \\
D (NX) & -5.2725 & -3.6793 & -2.9677 & 2.6229 & Stationary \\
& & & & - & \\
D (GFCF) & -3.4446 & -3.6793 & -2.9677 & 2.6229 & Stationary
\end{tabular}

Source: Author's Calculation

\section{Estimation of the Long Term Model}

After knowing that all variables used in the study meet the stationary test requirements for the use of the ECM model, we can proceed to establish the long term model. The estimation method, as written in (1), is done using the Ordinary Least Square (OLS).
Table 3. Estimation of the Long Term Model

\begin{tabular}{|c|c|c|c|c|}
\hline $\begin{array}{l}\text { Dependent } \\
\text { Variable: } \\
\text { LnGDP }\end{array}$ & Coefficient & Std. Error & t-stat & Prob \\
\hline$\alpha_{0}$ & 3.920994 & 0.162201 & 24.17364 & $0.0000 * *$ \\
\hline FDI & $-0,006458$ & 0.001873 & -3.462266 & $0.0019 * *$ \\
\hline HDI & 0.056924 & 0.002192 & 25.96926 & $0.0000 * *$ \\
\hline$N X$ & -0.001793 & 0.000771 & -2.327056 & $0.0284^{*}$ \\
\hline GFCF & 0.015482 & 0.002302 & 6.725923 & $0.0000 * *$ \\
\hline Crisis & -0.084126 & 0.023736 & -3.544226 & $0.0016 * *$ \\
\hline $\mathrm{R}^{2}$ & 0.993168 & F-stat & \multicolumn{2}{|c|}{726.8893} \\
\hline Adj. $R^{2}$ & 0.991802 & $\begin{array}{l}\text { Prob. F- } \\
\text { stat }\end{array}$ & \multicolumn{2}{|c|}{0.000000} \\
\hline & & Dw-stat & \multicolumn{2}{|c|}{1.147640} \\
\hline
\end{tabular}

Source: Author's Calculation

${ }^{* *}$ ) significant at $1 \%$ level, *) significant at $5 \%$ level

As seen from Table 3, the result of the $F$ test calculation is 726.8893 , with a p-value of 0.0000 . The P-value, which is less than 5 percent significance, leads to the decision to reject Ho. Thus, it concluded that there is at least one independent variable that affects economic growth.

The Long term equation is as follow:

$$
L N G D P_{t}=3,9209-0,0064 F D I_{t}
$$

$$
\begin{aligned}
& +0,0569 \text { HDI }_{t}-0,0017 N X_{t} \\
& +0,0154 G F C F_{t} \\
& -0,0841 \text { Crisis }_{t}
\end{aligned}
$$

The model has a coefficient of determination (Adjusted) of 0.9918, which indicates that $99.18 \%$ of the dependent variable's variation explained by the independent variables in the model. The long term model partially shows that the greater the Human Development and Gross Fixed Capital Formation will significantly affect economic growth in a positive direction. Meanwhile, the greater the Foreign Direct Investment, Trade Balance, and Economic Crisis value in the long term will significantly affect economic growth in a negative direction.

Foreign Direct Investment has a negative coefficient $(-0.0064)$, with a probability value of 0.0019 or significant at 1 percent level. This result is in line with the findings by Borenztein et al. (2001) and Alfaro (2003). It demonstrates that in the long run there is a negative correlation between FDI and economic growth in Indonesia. An increase in FDI by 1 million USD decreases economic growth by -0.0064 percent.

Trade Balance and the dummy of the Economic crisis, with each of the negative coefficient values $(-0.0017)$ and $(-0.084)$ that 


\section{The Effect of Foreign Direct Investment, Human Development and Macroeconomic Condition on Economic Growth: Evidence from Indonesia}

significant at 5 and 1 percent respectively show results that in line with the findings by Adhikary (2011) and Aisyah (2011). This coefficient suggests that an increase in Trade Balance by 1 million USD decreases economic growth by 0.0017 percent. The dummy of the economic crisis indicates that Indonesia's economic growth will be 0.084 percent smaller compared to the condition before the crisis.

In contrast, Human Development has a positive coefficient $(0.0569)$, with a probability value of 0.0000 or significant at 1 percent level. This result is in line with the findings by Ranis et al. (2000). It demonstrates that in the long run there is a positive correlation

between $\mathrm{HDI}$ and economic growth in Indonesia. An increase in $\mathrm{HDI}$ by 1 point increases economic growth by 0.056 percent. Gross Fixed Capital Formation (GFCF) has a positive coefficient $(0.0154)$ in line with the findings by Adhikary (2011) and Aisyah (2011). With a probability value of 0.0000 or significant at a 1 percent level, it suggests that an increase in GFCF by 1 million USD increases economic growth by 0.015 percent.

\section{Cointegration}

It assumed that these variables have cointegration. Cointegration can mean that there is a long-term relationship or balance between variables (Rosadi, 2016). By using the Johansen Cointegration, the statistic of the Unrestricted Cointegration Rank Test (Trace) at significance level $\alpha=0.05$ as presented in Table 4 show that at least 3 cointegration equation. This conclusion means that this model has cointegration or has a long term relationship.

\section{Table 4. Cointegration Test Using Johansen \\ Cointegration Test} Source: Author's Calculation

\section{Estimation of the Short Term Model}

The residual value resulted from the long term equation is used as Error Correction Term (ECT) in the short term model. The equation constructed based on the results of the test that all variables have been stationary in the first difference.

Table 5. Estimation of the Short Term Model

\begin{tabular}{|c|c|c|c|c|}
\hline $\begin{array}{l}\text { Dependent } \\
\text { Var: } \\
\text { D(LnGDP) }\end{array}$ & Coefficient & $\begin{array}{l}\text { Std. } \\
\text { Error }\end{array}$ & t-stat & Prob. \\
\hline$\beta_{0}$ & 0.001848 & 0.005937 & 0.311243 & 0.7584 \\
\hline $\mathrm{D}(\mathrm{FDI})$ & -0.001392 & 0.000993 & 1401072 & 0.1745 \\
\hline
\end{tabular}

\begin{tabular}{|c|c|c|c|c|}
\hline $\mathrm{D}(\mathrm{HDI})$ & 0.061972 & 0.009283 & 6.675 .997 & $0.0000^{\star \star}$ \\
\hline $\mathrm{D}(\mathrm{NX})$ & -0.000127 & 0.000458 & $\overline{0} .277693$ & 0.7837 \\
\hline $\mathrm{D}$ (GFCF) & 0.006063 & 0.001625 & 3.730 .549 & $0.0011^{\star *}$ \\
\hline
\end{tabular}

Table 5. Estimation of the Short Term Model -(Continued)

\begin{tabular}{|c|c|c|c|c|}
\hline $\begin{array}{l}\text { Dependent } \\
\text { Variable:D(LnGDP) }\end{array}$ & Coefficient & $\begin{array}{l}\text { Std. } \\
\text { Error }\end{array}$ & t-stat & Prob. \\
\hline Crisis & -0.078543 & 0.012471 & 6.297 .855 & $0.0000^{\star *}$ \\
\hline $\mathrm{ECT}(-1)$ & -0.569999 & 0.148879 & $\overline{3} .828 .617$ & $0.0009^{* *}$ \\
\hline$R^{2}$ & 0.896542 & F-stat & 3.321 .877 & \\
\hline $\begin{array}{l}R^{2} \\
\text { Adj. }\end{array}$ & 0.869553 & $\begin{array}{l}\text { Prob. F- } \\
\text { stat } \\
\text { Dw-stat }\end{array}$ & 0.000000 & \\
\hline
\end{tabular}

Source: Author's Calculation

${ }^{* *}$ ) significant at $1 \%$ level, *) significant at $5 \%$ level

The calculated short term equation, as seen in Table 5, produces the Error Correction Term (ECT), which is negative and significant. This result means that the model is robust, and the mechanism of error correction is running well. It also provides a system that can return to the long term steady trajectory. The model also meets the classical assumption of Normality, Homoscedasticity, Non-Multicollinearity, and No Autocorrelation (See Appendix).

For the independent variables $\mathrm{D}(\mathrm{HDI})$, D(GFCF), and Crisis, estimator produces similar results in terms of the sign and statistical significance. Nevertheless, the magnitudes of the estimated coefficient are slightly different from the long term equation. We found a positive relationship between the Human

Unrestricted Cointegration Rank Test (Trace)

\begin{tabular}{ccccc}
\cline { 1 - 3 } Hypothesized & & Trace & 0.05 & \\
No. of CE(s) & Eigenvalue & Statistic & $\begin{array}{c}\text { Critical } \\
\text { Value }\end{array}$ & Prob.** \\
\hline None * & 0.804008 & 117.0386 & 69.81889 & 0.0000 \\
At most 1 * & 0.701657 & 71.40763 & 47.85613 & 0.0001 \\
At most 2 * & 0.617692 & 37.54128 & 29.79707 & 0.0053 \\
At most 3 & 0.313303 & 10.61847 & 15.49471 & 0.2361 \\
At most 4 & 0.003364 & 0.094337 & 3.841466 & 0.7587
\end{tabular}

Trace test indicates 3 cointegrating eqn(s) at the 0.05 level

${ }^{*}$ denotes rejection of the hypothesis at the 0.05 level

*MacKinnon-Haug-Michelis (1999) p-values

Development Index and Gross Fixed Capital 
Formation and economic growth, while the economic crisis has a negative relationship with economic growth. We also found that in the short run, Foreign Direct Investment does not have any significant impact on economic growth.

This ECM model suggests that in the short run, a 1 percent increase in the Human Development Index increases economic growth by 0.06 percent. A 1 percent increase in GFCF increases economic growth by 0.006 percent. Furthermore, in the short run, Indonesia's economic growth will be 0.07 percent smaller compared to the condition before the crisis.

\section{The Effect of Foreign Direct Investment, Human Development and Macroeconomic Condition on Economic Growth}

Foreign Direct Investment, which in the long term provides a negative effect, in the short term, does not have any significant impact on economic growth. The presence of FDI in Indonesia aggravated by the lack of availability supporting facilities such as skilled labor and inadequate technology. On the other hand, the contribution of FDI as a driving force of economic growth in Indonesia is still not optimal due to many problems faced such as, upholding the rule of law, labor law, regional autonomy, and another issue which leads to unconducive of the investment climate.

In some cases, investment aimed at other countries might be harmful to the economic growth of the host country. FDI Inflows appeared to have a "market-stealing effect", a condition in which the domestic firm is not as productive as the foreign ones. Thus, the business with a smaller market average will leave the market, then the foreign industry benefits due to the increase in productivity. In the long run, this condition will be harmful to the recipient country as the FDI's negative influence weakens the competitive position of local producers and resulted in structural unemployment. Moreover, a few bad impacts of FDI are the exploitation of resources and employer with underweight salary, nature disaster with toxic waste around neighborhood and policy breaker as the corruption gap goes along with politics.

In contrast, Human Development has a positive effect on economic growth, both in the long term and short term. As people become healthier, better nourished, and educated, they will contribute more to economic growth. It affects the economy through a major contribution of enhancing people's capabilities, and consequently their creativity, and productivity. The existence of positive and significant impact of Human Development on economic growth can occur due to the strong national commitment to improving human development in many aspects, including economic, health, and education, which are measured by the increase of HDI each year.

To address the problem of high youth unemployment rate and lacking of skilled labor, the government regulates a grant double income tax deductions for companies that conduct vocational training and apprenticeship programs for unemployed graduates or job seekers and triple tax deductions for expenditures on research and development. Besides, the increase in health expenditure has contributed to good access to community health services. This improvement is certainly able to contribute positively to improving the productivity and creativity of workers in producing output effectively and efficiently.

Macroeconomic condition, firstly by Trade Balance, is mainly caused by a deterioration condition, in which the deficit is higher than the surplus that occurs in recent years. This condition caused developing countries like Indonesia to depend on the developed ones, on the other side, causing market domestic products to become limited. In the long run, many small industries will be out of business due to incompetence. Besides, the fundamental of Indonesia's economy is very vulnerable to crises and other external shocks. This condition can be seen from the exercise of the dummy of the economic crisis which gave negative results in the long and short run. In contrast, Gross Fixed Capital Formation that brings a more positive impact in the long run and short run has taken a significant contribution alongside household consumption to push Indonesia's economic growth. Capital formation ensures needed finance for the industries' growth and development, which is investment can support economic growth by absorbing a labor force.

\section{Conclusions}

This study analyses the effect of Foreign Direct Investment, Human Development, and Macroeconomic condition on economic growth in Indonesia from 1985 to 2015 using the Error Correction Model. The estimation equation indicated that Foreign Direct Investment in the long term has a negative effect on economic growth, while in the short term has no significant effect. In reverse, Human Development has a positive effect on economic growth both in the long term and short term. Macroeconomic conditions, which represent by Trade Balance, 


\section{The Effect of Foreign Direct Investment, Human Development and Macroeconomic Condition on Economic Growth: Evidence from Indonesia}

Gross Fixed Capital Formation, and the dummy of economic crises state a varied result, where Trade Balance and economic crises have a negative effect on economic growth, while Gross Fixed Capital Formation has a positive effect on economic growth.

To be able to enhance the economic growth in Indonesia, the government should be able to create a favorable investment climate by simplifying the bureaucracy in the licensing investment business and improving better service at the integrated one-door licensing system to reduce the length of business licensing time. The investment will bring a great impact that requires the government for the restructuring of policy to make them easier. Besides, Indonesia must start to strengthen the resilience of the national economy by utilizing locally based products. In addition to boosting the domestic economy, Indonesia will also be stronger from external shocks. With Human Development, our findings suggest that a focus on Human Development must be included from the beginning of any program. Following Borenztein et al. (2001), not only will create sustainable economic growth, but Human Development will also help to create a better Foreign Direct Investment in a country.

The study of how Foreign Direct Investment, Human Development, and Macroeconomic Conditions affect countries' economic growth is interesting future research, especially in developing countries. In this study, we have not incorporated the analysis of the interactions between Foreign Direct Investment and Human Development in a dynamic linear model that seems to be a subject for further research.

\section{REFERENCES}

Adhikary, B.K. (2011). FDI, Trade Openness, Capital Formation, and Economic Growth in Bangladesh: A Linkage Analysis, International Journal of Business and Management, 6(1): 16-28

Aisyah F. Y (2011). Analisis Pengaruh Foreign Direct Investment (FDI) terhadap Pertumbuhan Ekonomi ASEAN 19802009 [Skripsi], Departemen IImu Ekonomi: Fakultas Ekonomi dan Manajemen Institut Pertanian Bogor

Alfaro, L. (2003). Foreign Direct Investment and Growth: Does the Sector Matter? Harvard Business School, Harvard University, Working Paper, 14:1-31
Blomstrom, M., and Ari Kokko. (2003) Human Capital and Inward FDI. Working Paper 167. Stockholm. Sveavägen 65

Borenztein, E., J.De Gregorio, and J.W. Lee (2003). Human Capital and Inward FDI? European Commission under the Training and Mobility of Researchers Programme. CEPR Research Network

Cao, X. and Jariyapan, P. (2012). Foreign Direct Investment, Human Capital and Economic Growth of People's Republic of China Using Panel Data Approach

Carkovic. M and Levine. R (2002). Does Foreign Direct Investment Accelerate Economic Growth? Working Paper, University of Minnesota

Eurostat (2013). Handbook on Quarterly National Accounts. Eurostat manuals and guidelines

Gujarati, D.N. (2004). Basic Econometric (4th edition), New York: Mc Graw Hill Companies

Hady, H. (2001). Ekonomi Internasional Teori dan Kebijakan Keuangan Internasional Buku 2. Penerbit Ghalia Indonesia, Jakarta

Kotler, P. Jatusripitak, S, and Suvit. M (1997). The Marketing of Nations. The Free Press: A Division Simon \& Schuster Inc., New York. 1997

Kuznets, S (1973). Modern Economic Growth: Findings and Reflections. American Economic Review

Ranis, G, and Ramirez, A. (2000). Economic Growth and Human Development. Journal of World Development Vol. 28, No. 2, pp. 197-219

Rivayani (2003). Dampak FDI terhadap Pertumbuhan Ekonomi ASEAN-5 dalam kaitannya dengan level Human Capital [Skripsi]. Jakarta: FEUI

Rosadi, Dedi (2016). Analisis Ekonometrika \& Runtun Waktu Terapan dengan $R$. Gadjah Mada Press. Yogyakarta

Salvatore, D. (1996). International Economics. John Wiley \& Sons. New York

Statistics Indonesia. (2015). Human Development Index 2014. Jakarta. BPS

Todaro, M. P and S.C. Smith (2017). Economic Development. $12^{\text {th }}$ Edition. The 
Pearson Series in Economics. TransAtlantic Publications. Philadelphia

Tulus, Tambunan (2011). Perekonomian Indonesia: Kajian Teoritis dan Analisis Empiris. Bogor. Penerbit Ghalia Indonesia. Jakarta

United Nations Development Programme (1990). Human Development Report 1990. New York. Oxford University Press

World Economic Forum. (2016). The World's 10 biggest economies in 2017. 20 Juli 2017https://www.weforum.org/agendal 2017/03/worldsbiggesteconomies- in$\underline{2017}$

\section{APPENDIX}

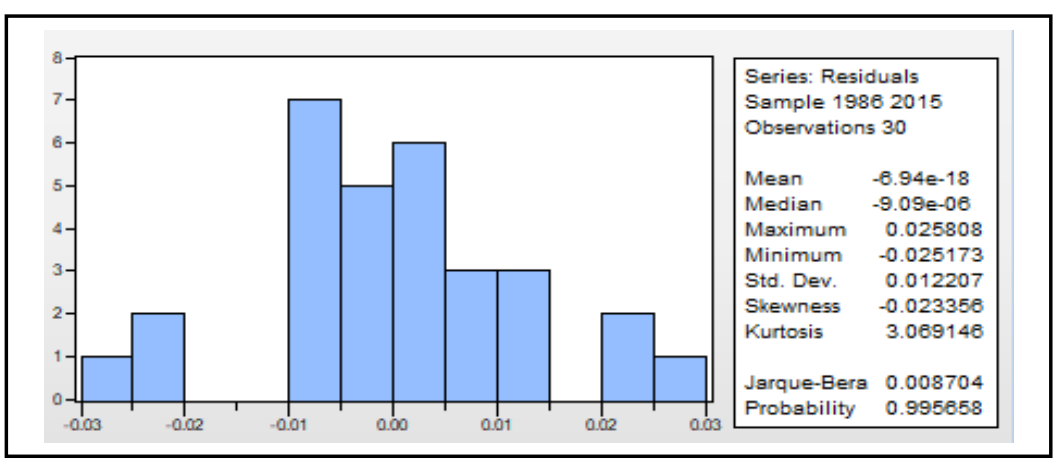

Breusch-Godfrey Serial Correlation LM Test:

\begin{tabular}{llll}
\hline \hline F-statistic & 2.208539 & Prob. F(2,21) & 0.1347 \\
Obs*R-squared & 5.213515 & Prob. Chi-Square(2) & 0.0738 \\
\hline \hline
\end{tabular}

Breusch-Godfrey Serial Correlation LM Test:

\begin{tabular}{llll}
\hline \hline F-statistic & 2.208539 & Prob. $F(2,21)$ & 0.1347 \\
Obs*R-squared & 5.213515 & Prob. Chi-Square(2) & 0.0738 \\
\hline \hline
\end{tabular}

Variance Inflation Factors

Date: 06/27/20 Time: 09:39

Sample: 19852015

Included observations: 30

\begin{tabular}{cccc}
\hline \hline Variable & $\begin{array}{c}\text { Coefficient } \\
\text { Variance }\end{array}$ & $\begin{array}{c}\text { Uncentered } \\
\text { VIF }\end{array}$ & $\begin{array}{c}\text { Centered } \\
\text { VIF }\end{array}$ \\
\hline \hline C & $3.53 E-05$ & 5.628610 & NA \\
D(FDI) & $9.87 \mathrm{E}-07$ & 1.679762 & 1.613412 \\
D(HDI) & $8.62 \mathrm{E}-05$ & 6.776428 & 2.078428 \\
D(NX) & $2.10 \mathrm{E}-07$ & 1.480480 & 1.479936 \\
D(GFCF) & $2.64 \mathrm{E}-06$ & 1.361551 & 1.318871 \\
CRISIS & 0.000156 & 1.655639 & 1.545263 \\
ECT(-1) & 0.022165 & 1.969494 & 1.969489 \\
\hline
\end{tabular}

